\title{
12-Lipoxygenase promotes invasion and metastasis of human gastric cancer cells via epithelial-mesenchymal transition
}

\author{
CANMEI ZHONG, MINGKAI ZHUANG, XIAZHONG WANG, JIANYING LI, \\ ZHIXIN CHEN, YUEHONG HUANG and FENGLIN CHEN
}

\author{
Department of Gastroenterology, Fujian Medical University Union Hospital, Fuzhou, Fujian 350001, P.R. China
}

Received October 10, 2017; Accepted March 22, 2018

DOI: $10.3892 /$ ol.2018.8808

\begin{abstract}
The role of 12-lipoxygenase (12-LOX) in tumorigenesis has been well established in several types of human cancer, including gastric cancer. It was reported that epithelial-mesenchymal transition (EMT) contributes to tumor invasion and metastasis. However, whether 12-LOX promotes the invasion and metastasis of human gastric cancer cells via EMT remains to be elucidated. In the present study, the expression of 12-LOX and EMT markers, N-cadherin and E-cadherin, was evaluated in gastric cancer and adjacent normal mucosa samples by immunohistochemical analysis. 12-LOX-overexpressing gastric cancer cells were established via lentiviral transfection of SCG-7901 cells. Wound-healing and Transwell assays were performed to examine the regulation of cell metastasis and invasion by $12-\mathrm{LOX}$. Furthermore, the regulation of $\mathrm{N}$-cadherin expression by 12-LOX was evaluated using reverse transcription-quantitative polymerase chain reaction and western blotting. The results revealed that the expression of 12 -LOX and $\mathrm{N}$-cadherin was significantly higher in gastric cancer compared with that in adjacent normal mucosa tissues $(\mathrm{P}<0.05)$. By contrast, the expression of E-cadherin was significantly decreased in gastric cancer compared with that in adjacent normal mucosa tissues $(\mathrm{P}<0.05)$. Furthermore, the expression of 12 -LOX was positively associated with $\mathrm{N}$-cadherin expression in gastric cancer tissues. 12-LOX-overexpressing gastric cancer cells exhibited significantly increased invasion and migration abilities compared with the empty vector and control groups. The expression of $\mathrm{N}$-cadherin in 12-LOX-overexpressing gastric cancer cells was increased compared with that in the empty vector and control groups. The present study suggests that EMT may be involved in the promotion of the invasion and metastasis of human gastric cancer cells by 12-LOX.
\end{abstract}

Correspondence to: Dr Fenglin Chen, Department of Gastroenterology, Fujian Medical University Union Hospital, 29 Xinquan Road, Fuzhou, Fujian 350001, P.R. China

E-mail: drchenflxiehe@163.com

Key words: gastric carcinoma, 12-lipoxygenase, epithelial-mesenchymal transition, invasion, metastasis

\section{Introduction}

Gastric cancer (GC) is a type of gastrointestinal cancer that is commonly diagnosed at an advanced stage. Gastric cancer remains the second leading cause of cancer mortality in China (1). Invasion and metastasis are hallmarks of cancer, and affect the mortality rates of GC (2).

12-LOX is an isozyme of the LOX superfamily, and previous studies have suggested that LOX isozymes, including 12-LOX, are implicated in tumor progression (3). 12-LOX, or its metabolic product, 12-HETE, promotes progression and metastasis in several types of solid tumors, including prostate cancer (4), breast cancer (5), colon cancer (6) and melanoma (7). The role of 12-LOX in the invasion and metastasis of human GC, and its underlying mechanism, remain to be elucidated.

Tumor cells acquire invasive/metastatic properties due to epithelial-mesenchymal transition (EMT), whereby the epithelial cell layers lose polarity and cell-cell adhesion due to remodeling of the cytoskeleton (8). EMT is involved in a variety of processes that characterize tumor progression, including cell invasion and metastasis $(9,10)$. The hallmarks of EMT are the upregulation of $\mathrm{N}$-cadherin and the downregulation of E-cadherin expression (11). N-cadherin is a member of the cadherin superfamily, which regulates cell-cell adhesion (12), and has been demonstrated to increase the motility and migration abilities of a number of types of cancer cells $(13-15)$ and be a marker of EMT $(16,17)$. E-cadherin is a $\mathrm{Ca}^{2+}$-dependent cell-cell adhesion molecule that is important for maintaining the integrity and polarity of epithelial cells (18). Numerous studies have indicated that downregulation of E-cadherin results in tumor progression, metastasis and a poor prognosis for patients with GC (19-22), cervical carcinoma (23), colorectal cancer (24) and cholangiocarcinoma (25).

The aim of the present study was to investigate the role of 12-LOX in the invasion and metastasis of human GC, and to determine whether the effects of $12-\mathrm{LOX}$ are mediated through EMT.

\section{Patients and methods}

Patient selection and tissue preparation. The present study was approved by the Ethics Committee of the Fujian Medical 
University Union Hospital (Fuzhou, China; reference no. 2014KY031) and written informed consent was obtained from each patient. A total of 105 paraffin-embedded GC tissue samples and 43 adjacent normal gastric mucosa tissue samples were randomly selected from the Department of Pathology, Fujian Medical University Union Hospital (Fuzhou, China), for retrospective study. The GC cases consisted of 80 men and 25 women, aged 34-81 years (mean age, 57 years), between October 2011 and December 2014. Tumors were staged according to the 7th edition of the AJCC Cancer Staging Manual: Stomach (26). The clinicopathological characteristics of the patients are summarized as follows (some data missing): Tumor size $(<5 \mathrm{~cm}, 53$ cases; $\geq 5 \mathrm{~cm}$, 52 cases); tumor invasion (T1-T2, 28 cases; T3-T4, 76 cases); differentiation (poor, 52 cases; middle-well, 42 cases); clinical stage (I+II, 44 cases; III+IV, 61 cases); lymph nodes metastasis (negative, 26 cases; positive, 78 cases). All patients were treated by radical surgical resection and had not received chemotherapy or radiotherapy prior to surgery.

Immunohistochemistry. Formalin-fixed and paraffin-embedded specimens from the Department of Pathology were sectioned at a thickness of $4-\mu \mathrm{m}$, then deparaffinized twice in 100\% dimethylbenzene for $30 \mathrm{~min}$, then rehydrated in a graded ethanol series $(100,95,70$ and $50 \%$ ). The slides were placed in antigen retrieval buffer (sodium citrate $10 \mathrm{mM}, \mathrm{pH} \mathrm{6.0)}$ and microwaved at high power for $15 \mathrm{~min}$, followed by blocking endogenous peroxidase activity in $0.3 \%$ hydrogen peroxide for $20 \mathrm{~min}$ at room temperature. Protein expression was detected using the following primary antibodies: 12-LOX (dilution 1:100; cat. no. GTX80966), E-cadherin (dilution, 1:500; cat. no. GTX100443) and N-cadherin (dilution 1:150; cat. no. GTX12221; all GeneTex, Inc., Irvine, CA, USA), which were incubated with the sections overnight at $4^{\circ} \mathrm{C}$. The slides were then incubated with secondary antibodies for $20 \mathrm{~min}$ in a humidified chamber at $37^{\circ} \mathrm{C}$. All slides were stained with $10 \% 3^{\prime}$-diaminobenzidine (OriGene Technologies, Inc., Beijing, China) for $2 \mathrm{~min}$ at room temperature, washed with PBS and then stained with $0.1 \%$ hematoxylin for $3 \mathrm{~min}$ at room temperature. The sections were washed again with PBS and then washed with running tap water for $10 \mathrm{~min}$. All the slides were observed under a light microscope (magnification, $\mathrm{x} 400$ ) in 10 randomly selected fields of view, and qualitatively scored by 2 pathologists. The final score was based on the percentage of positively stained cells as follows: $0,1 \% ; 1,1-25 \% ; 2,25-50 \% ; 3,50-75 \%$; and $4,>75 \%$. This was multiplied by the intensity of the staining, which was scored as follows: 0 , none; 1 , weak; 2 , moderate, and 3 , strong. Scores of $\leq 3$ were considered to indicate negative expression, whereas scores $\geq 4$ were considered to indicate positive expression.

Cell culture. The human GC cell line, SGC-7901 (The Department of Gastroenterology, Fujian Medical University Union Hospital), was cultured in DMEM (HyClone; GE Healthcare, Chicago, IL, USA) supplemented with $10 \%$ fetal bovine serum (HyClone; GE Healthcare) at $37^{\circ} \mathrm{C}$ in $5 \% \mathrm{CO}_{2}$.

Lentivirus vector construction and transfection. The lentivirus vector for 12-LOX gene overexpression was constructed by
Shanghai GeneChem Co., Ltd. (Shanghai, China). An empty green fluorescent protein (GFP) vector was used as a negative control (Shanghai GeneChem Co., Ltd.). A total of $6 \times 10^{4}$ SGC-7901 cells were seeded in each well of a 6-well plate. When confluency reached $30-40 \%$, the 12-LOX overexpression vector $\left(2 \times 10^{7} \mathrm{TU} / \mathrm{ml}\right)$ or the empty GFP vector $\left(2 \times 10^{7} \mathrm{TU} / \mathrm{ml}\right)$ was transfected into the SGC-7901 cells. The status of cells was observed by fluorescence microscope (magnification, x200) for 8-12 h, according to the lentivirus vector manufacturer's instructions, and the medium was replaced. When confluency reached $90 \%$, the cells was transferred into a culture flask. Following transfection, cells were used in subsequent experiments after 2 passages. Three groups of cells were used in the subsequent experiments: Untransfected cells (control group), cells transfected with the empty GFP vector (LV-vector group) and cells transfected with the 12-LOX expression vector (LV-12-LOX group).

Wound-healing assay. A total of $4 \times 10^{5}$ cells were seeded into each well of a 6-well plate and allowed to grow in DMEM supplemented with $10 \%$ fetal bovine serum (both HyClone; GE Healthcare, Chicago, IL, USA) until $\sim 100 \%$ confluent. A 200- $\mu 1$ pipette tip was used to scratch across the cell monolayer. Cellular debris was removed by washing with PBS three times, and the plate was cultured for another $24 \mathrm{~h}$. Images were captured at 0 and $24 \mathrm{~h}$ after wounding using an inverted light microscope. The extent of wound-healing was quantified using the following formula: $\left(\mathrm{W}_{0 \mathrm{~h}}-\mathrm{W}_{24 \mathrm{~h}}\right) / \mathrm{W}_{0 \mathrm{~h}}$, where $\mathrm{W}_{0 \mathrm{~h}}$ and $\mathrm{W}_{24}$ ${ }_{\mathrm{h}}$ represent the width of the wound at 0 and $24 \mathrm{~h}$, respectively.

Cell invasion and migration assay. A 24-well plate containing Transwell inserts with a pore size of $8 \mu \mathrm{m}$ (Merck KGaA, Darmstadt, Germany) was coated with Matrigel (BD Biosciences, Franklin Lakes, NJ, USA) for the invasion assay and left uncoated for the migration assay. The following steps were then performed for the two assays. A total of $1.5 \times 10^{4}$ cells suspended in serum-free DMEM were placed in the upper chamber. DMEM containing $10 \%$ fetal bovine serum was placed in the lower chamber as a chemoattractant. The cells were incubated for $24 \mathrm{~h}$ at $37^{\circ} \mathrm{C}$ prior to removal of cells remaining on the upper side of the chamber with a cotton swab. Cells on the lower side of the membrane were fixed in $4 \%$ paraformaldehyde for $10 \mathrm{~min}$ at room temperature and dyed with $0.1 \%$ crystal violet for $15 \mathrm{~min}$ at room temperature. The number of cells was then counted under an inverted light microscope (magnification, $\mathrm{x} 400$ ) by a technician blinded to the experimental settings in 5 randomly selected fields of view in each plate. The experiments were repeated 3 times.

Reverse transcription-quantitative polymerase chain reaction $(R T-q P C R)$ analysis. RT-qPCR was used to detect the mRNA expression of 12-LOX and $\mathrm{N}$-cadherin in the transfected and untransfected cells. Total RNA was extracted using TRIzol (Thermo Fisher Scientific, Inc., Waltham, MA, USA). cDNA was synthesized using $2 \mu \mathrm{g}$ total RNA using the PrimeScript ${ }^{\mathrm{TM}}$ RT reagent kit (Takara Biotechnology Co., Ltd. Dalian, China). RT-qPCR analysis was performed using SYBR ${ }^{\circledR}$ Premix Ex Taq $^{\text {TM }}$ II (Tli RNaseH Plus; Takara) with 7500 Fast Real-Time PCR System (Applied Biosystems; Thermo Fisher Scientific, 
Table I. Primer sequences for 12-LOX, N-cadherin and GAPDH.

\begin{tabular}{|c|c|}
\hline Gene & Primer $\left(5^{\prime}-3^{\prime}\right)$ \\
\hline \multirow[t]{2}{*}{ 12-LOX } & Forward:ATGGCCCTCAAACGTGTTTAC \\
\hline & Reverse: GCACTGGCGAACCTTCTCA \\
\hline \multirow[t]{2}{*}{ N-cadherin } & Forward: GCGTCTGTAGAGGCTTCTGG \\
\hline & Reverse: AAATCTGCAGGCTCACTGCT \\
\hline \multirow[t]{3}{*}{ GAPDH } & Forward:CATCAGCAATGCCTCCTGCAC \\
\hline & Reverse: TGAGTCCTTCCACGATACCAA \\
\hline & AGTT \\
\hline
\end{tabular}

12-LOX, 12-lipoxygenase.

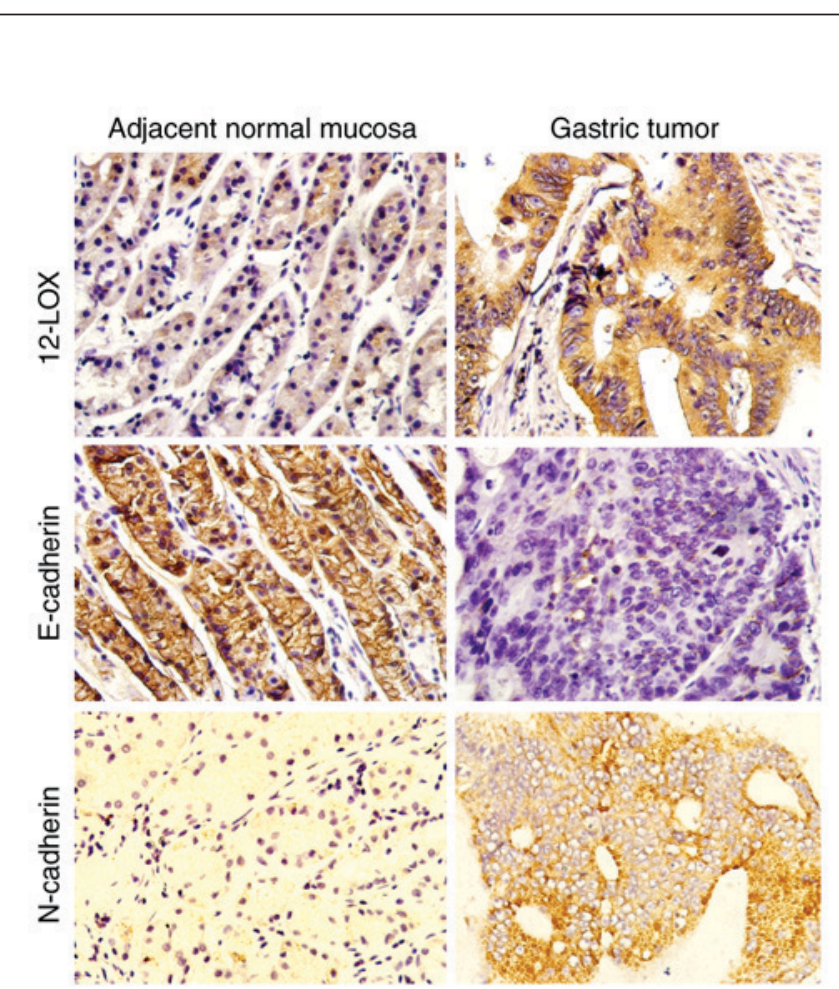

Figure 1. Representative expression levels of 12-LOX, E-cadherin and $\mathrm{N}$-cadherin in GC and adjacent normal gastric mucosa tissues, as analyzed by immunohistochemistry (magnification, $\mathrm{x} 400$ ). The protein expression level of 12-LOX and N-cadherin was increased, and that of E-cadherin was decreased, in GC tissue compared with adjacent normal gastric mucosa tissue. 12-LOX, 12-lipoxygenase; GC, gastric cancer.

Inc.). The PCR amplification was performed under the following conditions: $95^{\circ} \mathrm{C}$ for $2 \mathrm{~min}$, then 45 cycles of denaturation at $95^{\circ} \mathrm{C}$ for $15 \mathrm{sec}$, annealing at $63^{\circ} \mathrm{C}$ for $15 \mathrm{sec}$ and elongation at $72^{\circ} \mathrm{C}$ for $20 \mathrm{sec}$. The primer sequences for 12-LOX, $\mathrm{N}$-cadherin and GAPDH are listed in Table I (Shanghai Yaolin Bio-Technology Co., Ltd., Shanghai, China). The gene expression levels were normalized to GAPDH and are presented as relative fold change compared to the control (27). The data were analyzed using the $2^{-\Delta \Delta \mathrm{Cq}}$ method. A total of 3 independent repeat experiments were performed.

Western blotting analysis. Total protein was extracted using cell lysis buffer (Beyotime Institute of Biotechnology, Haimen, China) containing $1 \mathrm{mmol} / 1$ phenylmethylsulfonyl fluoride.
Table II. Expression of 12-LOX, N-cadherin and E-cadherin in 105 cases of gastric cancer and 43 gastric normal mucosa tissues.

\begin{tabular}{lccr}
\hline $\begin{array}{l}\text { Protein } \\
\text { expression }\end{array}$ & $\begin{array}{c}\text { Gastric } \\
\text { cancer tissue }\end{array}$ & $\begin{array}{c}\text { Gastric normal } \\
\text { mucosa tissue }\end{array}$ & P-value \\
\hline 12-LOX & & 14 & 0.001 \\
Positive & 65 & 29 & \\
Negative & 40 & & $<0.001$ \\
N-cadherin & & 11 & \\
Positive & 63 & 32 & 0.046 \\
Negative & 42 & & \\
E-cadherin & & 24 & \\
Positive & 41 & 19 & \\
Negative & 64 & & \\
\hline
\end{tabular}

$\chi^{2}$ test. 12-LOX, 12-lipoxygenase.

Protein concentration was determined using a bicinchoninic acid assay kit (Beyotime Institute of Biotechnology). A total of $40 \mu \mathrm{g}$ protein per lane was subjected to $10 \%$ SDS-PAGE and transferred to a nitrocellulose membrane (GE Healthcare, IL, Chicago). The membrane was blocked in 5\% skimmed milk dissolved by PBS for $2 \mathrm{~h}$ at room temperature and subsequently incubated with the following rabbit polyclonal primary antibodies overnight at $4^{\circ} \mathrm{C}$ : 12 -LOX (dilution 1:80; cat. no. GTX80966), N-cadherin (dilution 1:80; cat. no. GTX12221; both GeneTex, Inc.) or GAPDH (dilution 1:1,500; cat. no. TA309157; OriGene Technologies, Inc.). The membrane was then incubated with the appropriate HRP-conjugated Goat anti-Rabbit IgG (H+L) (dilution 1:2,000; cat. no. ZB2301; OriGene Technologies, Inc.) for $1 \mathrm{~h}$ at room temperature. The proteins were visualized using an ECL Advance Detection system (Origene Technologies, Inc.).

Statistical analysis. Data are expressed as the mean \pm standard deviation. The differentiation between expression levels and clinicopathological parameters were analyzed using the $\chi^{2}$ test. The associations between groups were compared using analysis of variance followed by the Least-Significant-Difference test. Statistical analyses were performed using SPSS 19.0 software (IBM Corp., Armonk, NY, USA). $\mathrm{P}<0.05$ was considered to indicate a statistically significant difference.

\section{Results}

Expression of 12-LOX, N-cadherin and E-cadherin in $G C$ tissue. Immunohistochemical analysis was used to evaluate the protein expression levels of 12-LOX, N-cadherin and E-cadherin in GC tissue and adjacent normal mucosa tissue. It was demonstrated that 12 -LOX and $\mathrm{N}$-cadherin were mainly expressed in the cytoplasm of tumor cells, whereas E-cadherin was localized in the cell membrane (Fig. 1). The protein expression level of 12 -LOX and $\mathrm{N}$-cadherin was significantly increased in GC tissue compared with that in 
Table III. Association between 12-LOX, E-cadherin and N-cadherin protein expression level and clinicopathological features in 105 cases of gastric cancer (some patient data is missing).

\begin{tabular}{|c|c|c|c|c|c|c|c|c|c|}
\hline \multirow[b]{2}{*}{ Characteristic } & \multicolumn{3}{|c|}{ 12-LOX expression } & \multicolumn{3}{|c|}{ E-cadherin expression } & \multicolumn{3}{|c|}{$\mathrm{N}$-cadherin expression } \\
\hline & Low, $\mathrm{n}$ & High, $n$ & P-value & Low, $\mathrm{n}$ & High, $n$ & P-value & Low, $\mathrm{n}$ & High, $n$ & P-value \\
\hline \multicolumn{10}{|l|}{ Age, years } \\
\hline$\leq 60$ & 18 & 29 & 0.751 & 34 & 13 & $0.031^{\mathrm{a}}$ & 21 & 26 & 0.291 \\
\hline$>60$ & 24 & 34 & & 30 & 28 & & 20 & 38 & \\
\hline \multicolumn{10}{|l|}{ Sex } \\
\hline Male & 35 & 45 & 0.164 & 46 & 34 & 0.198 & 31 & 49 & 0.912 \\
\hline Female & 7 & 18 & & 18 & 7 & & 10 & 15 & \\
\hline \multicolumn{10}{|l|}{ Tumor size, $\mathrm{cm}$} \\
\hline$<5$ & 24 & 29 & 0.296 & 32 & 21 & 0.902 & 27 & 26 & $0.011^{\mathrm{a}}$ \\
\hline$\geq 5$ & 18 & 34 & & 32 & 20 & & 14 & 38 & \\
\hline \multicolumn{10}{|l|}{ Tumor invasion } \\
\hline $\mathrm{T} 1-\mathrm{T} 2$ & 11 & 17 & 0.986 & 18 & 10 & 0.645 & 14 & 14 & 0.145 \\
\hline $\mathrm{T} 3-\mathrm{T} 4$ & 30 & 46 & & 45 & 31 & & 26 & 50 & \\
\hline \multicolumn{10}{|l|}{ Differentiation } \\
\hline Poor & 32 & 20 & 0.670 & 14 & 38 & $0.021^{\mathrm{a}}$ & 29 & 23 & 0.121 \\
\hline Middle-well & 24 & 18 & & 21 & 21 & & 30 & 12 & \\
\hline \multicolumn{10}{|l|}{ Clinical stage } \\
\hline I+II & 17 & 27 & 0.811 & 29 & 15 & 0.381 & 19 & 25 & 0.466 \\
\hline III+IV & 25 & 36 & & 35 & 26 & & 22 & 39 & \\
\hline \multicolumn{10}{|c|}{ Lymph node metastasis } \\
\hline Negative & 9 & 17 & 0.562 & 16 & 10 & 0.908 & 11 & 15 & 0.645 \\
\hline Positive & 32 & 46 & & 47 & 31 & & 29 & 49 & \\
\hline
\end{tabular}

$\chi^{2}$ test. 12-LOX, 12-lipoxygenase. ${ }^{\mathrm{a}} \mathrm{P}<0.05$.

adjacent normal gastric mucosa tissue $(\mathrm{P}<0.05$; Table II). By contrast, the expression of E-cadherin was significantly decreased in GC tissues compared with that in adjacent normal gastric mucosa tissue $(\mathrm{P}<0.05)$. The associations between patient clinicopathological characteristics and the protein expression levels of 12-LOX, N-cadherin and E-cadherin were examined. As demonstrated in Table III, there was a close association between the levels of E-cadherin protein expression and two factors, patient age and tumor differentiation $(\mathrm{P}<0.05)$, whereas the level of $\mathrm{N}$-cadherin protein expression was associated with tumor size $(\mathrm{P}<0.05)$. 12-LOX expression was higher in tumors $\geq 5 \mathrm{~cm}$, with a depth of invasion of T3-T4 and clinical stage of III+IV, however, these differences were not statistically significant $(\mathrm{P}>0.05)$. The expression of 12-LOX was positively associated with that of $\mathrm{N}$-cadherin in GC tissues ( $\mathrm{r}=0.263$; $\mathrm{P}=0.007$; Table IV).

12-LOX promotes the migration and invasion of GC cells. A stably transfected 12-LOX-overexpressing GC SGC-7901 cell line was established, and the green fluorescent cells were $>95 \%$ confluent prior to fluorescence microscopy (magnification, x200). The results of RT-qPCR and western blotting revealed that the expression of 12-LOX in the LV-12-LOX group was significantly increased compared with that in the LV-vector and control groups (Fig. 2A).
Table IV. Association between the expression levels of 12-LOX and N-cadherin protein expression in 105 gastric cancer tissues.

\begin{tabular}{lcccc}
\hline & \multicolumn{4}{c}{ 12-LOX expression } \\
\cline { 2 - 5 } $\begin{array}{l}\text { N-cadherin } \\
\text { expression }\end{array}$ & Low & High & $\mathrm{R}$ & P-value \\
\hline Low & 23 & 18 & 0.263 & 0.007 \\
High & 19 & 45 & & \\
\hline
\end{tabular}

$\chi^{2}$ test. 12-LOX, 12-lipoxygenase.

The results of the scratch wound-healing (Fig. 2B) and Transwell (Fig. 2C) assays demonstrated that 12-LOX promotes the migration and invasion of GC cells in vitro. Significantly more cells migrated in $24 \mathrm{~h}$ in the LV-12-LOX group compared with those in the $\mathrm{LV}$-vector and control groups $(\mathrm{P}<0.05)$. The number of cancer cells that invaded through the Matrigel was significantly higher in the LV-12-LOX group compared with that in the LV-vector and control groups $(\mathrm{P}<0.05)$.

The results of RT-qPCR revealed that the mRNA level of $\mathrm{N}$-cadherin was significantly increased in the LV-12-LOX 
A
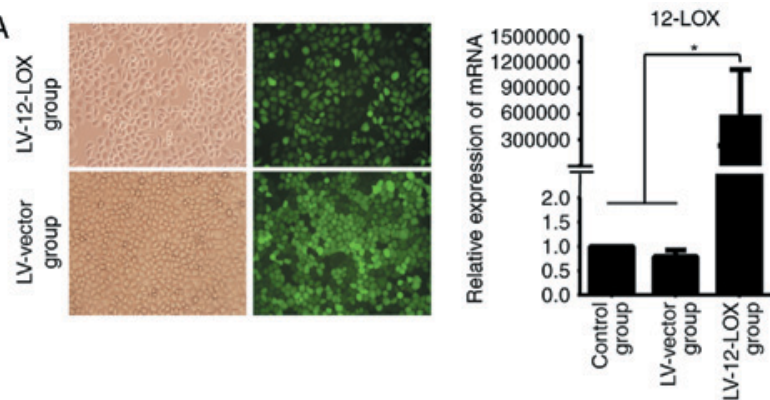

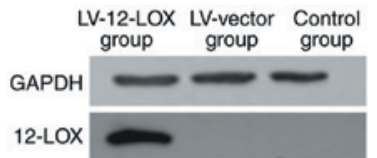

12-LOX

B
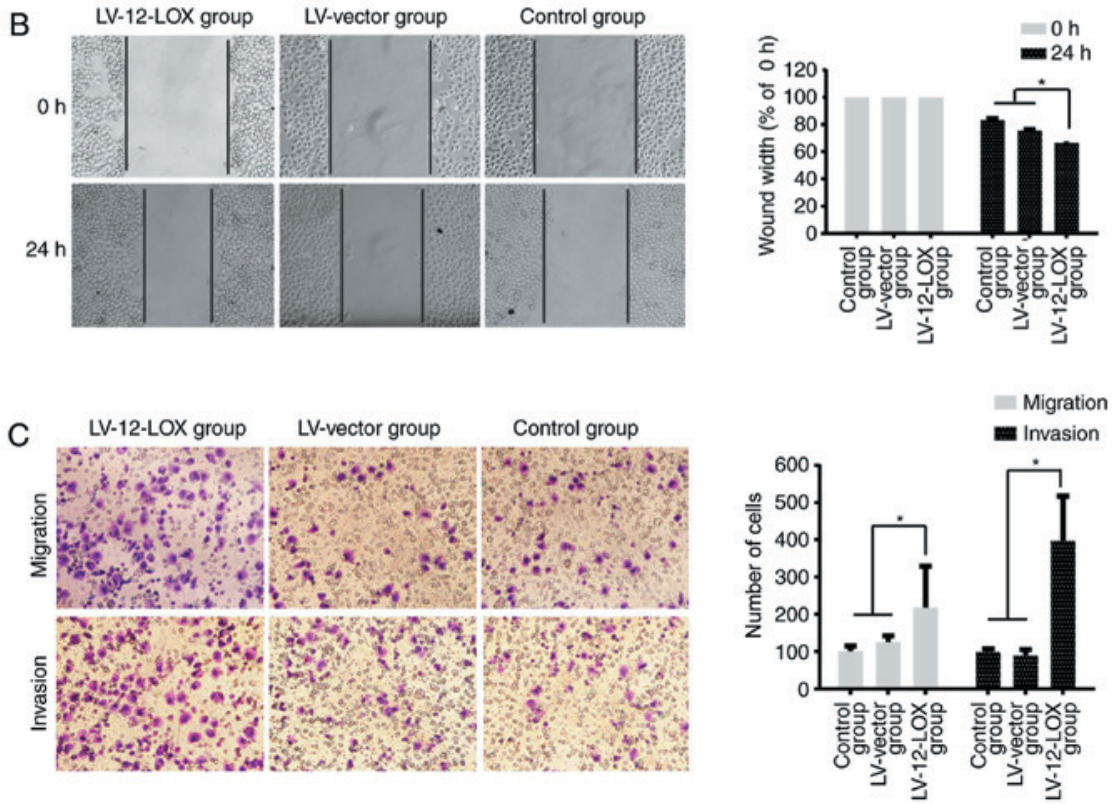

Figure 2. SGC-7901 GC cells were transfected with the 12-LOX overexpression vector or empty vector. (A) Successfully transfected cells fluoresced green The mRNA expression of 12-LOX was significantly increased in the LV-12-LOX group compared with that in the LV-vector and control groups ("P<0.05), which was reflected at the protein level. (B) The wound-healing assay demonstrated the migration of the 3 groups at 0 and $24 \mathrm{~h}$. The migratory ability of LV-12-LOX GC cells was significantly increased compared with the LV-vector and control group cells ( $\mathrm{P}<0.05)$. (C) Migration and invasion assays revealed that the number of cancer cells that migrated or invaded through the Transwell insert was significantly increased in the LV-12-LOX group compared with that in the LV-vector and control groups ( $\mathrm{P}<0.05)$. 12-LOX, 12-lipoxygenase; LV, lentivirus; GC, gastric cancer.

group compared with that in the LV-vector and control groups (Fig. 3A; $\mathrm{P}<0.05$ ). Western blotting revealed that the protein expression level of $\mathrm{N}$-cadherin was markedly increased in the LV-12-LOX group compared with that in the LV-vector and control groups (Fig. 3B).

\section{Discussion}

12-LOX serves an important role in various inflammatory diseases, including diabetes, atherosclerosis (28) and nervous system diseases (29). Previous research has reported significant functional roles of 12-LOX and its product, 12-HETE, in the formation, development, invasion and metastasis of several types of cancer (30-32). Klampfl et al (6) reported that upregulation of 12-LOX induced a migratory phenotype in colorectal cancer cells. The available literature regarding the expression and involvement of 12-LOX in GC is limited; however, it has been reported that 12-LOX may be associated with GC cell apoptosis $(33,34)$.

The present study demonstrated that 12 -LOX was highly expressed in GC tissue compared with that in adjacent normal gastric mucosa tissue, indicating that 12 -LOX overexpression may contribute to GC progression. LV-12-LOX

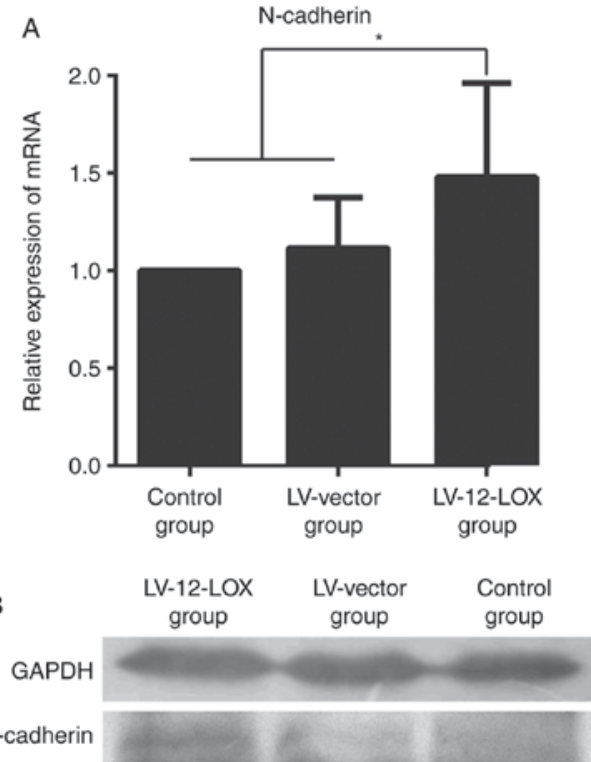

Figure 3. 12-LOX promotes $\mathrm{N}$-cadherin expression in gastric cancer cells (A) The mRNA expression level of $\mathrm{N}$-cadherin was determined by reverse transcription-quantitative polymerase chain reaction $\left({ }^{*} \mathrm{P}<0.05\right)$. (B) The protein expression level of $\mathrm{N}$-cadherin was determined by western blotting. 12-LOX, 12-lipoxygenase; LV, lentivirus. 
GC cells exhibited significantly enhanced migratory and invasive abilities compared with the LV-vector and control groups. These results indicate that 12 -LOX facilitates GC cell migration and invasion and are consistent with previous studies that reported that 12 -LOX promotes invasion and metastasis in numerous types of tumor cells (35-37). However, the specific underlying mechanism remains to be elucidated.

Immunohistochemical analysis revealed that GC tissue exhibited increased E-cadherin and decreased $\mathrm{N}$-cadherin protein expression levels compared with those of adjacent normal gastric mucosa tissues. Abnormal expression of E-cadherin was demonstrated to be significantly associated with tumor grade and patient age, which was also reported by Torabizadeh et al (38). Anbiaee et al (39) and Lazăr et al (40) reported a significant correlation between the abnormal expression of E-cadherin and tumor grade, but no correlation with patient age. The present study also revealed a significant association between the abnormal expression of $\mathrm{N}$-cadherin and tumor size, suggesting that $\mathrm{N}$-cadherin may promote the growth of GC.

The present study also demonstrated that the expression level of 12-LOX was positively associated with that of $\mathrm{N}$-cadherin in GC tissue. To the best of our knowledge, the regulation of $\mathrm{N}$-cadherin expression by 12 -LOX has not been previously reported. $\mathrm{N}$-cadherin is a member of the calcium-dependent cell adhesion molecule family, and a marker of interstitial cells (41). $\mathrm{N}$-cadherin is also a marker of EMT $(42,43)$, and serves a key role in tumor cell migration, invasion and metastasis $(44,45)$. It has been reported that EMT is involved in the invasion and metastasis of GC (46), which indicates that $12-\mathrm{LOX}$ may affect GC progression via EMT.

The present study suggests that EMT may be involved in the progression of GC, which is in accordance with previous study results $(9,10,46)$. Therefore, we hypothesize that 12-LOX promotes the invasion and metastasis of GC cells via EMT. Han and Xu (47) reported that epithelial membrane protein 3 is induced by twist family BHLH transcription factor $1 / 2$ and regulates the EMT of GC cells. Song et al (48) demonstrated that the $\mathrm{Wnt} / \beta$-catenin and phosphoinositide 3-kinase/protein kinase B signaling pathways regulate EMT in GC. Chen et al (49) reported that the tumor necrosis factor- $\alpha$-inducing protein of Helicobacter pylori induces EMT in GC cells through activation of the interleukin-6/signal transducer and activator of transcription 3 signaling pathway. Numerous other pathways are reportedly involved in EMT, including transforming growth factor $\beta$ (50), notch (51), nuclear factor- $\kappa \mathrm{B}$ (52) and mitogen-activated protein kinases/extracellular signal-regulated kinase signaling (53). The underlying mechanisms of the promotion of EMT by 12-LOX require further investigation.

In conclusion, it was demonstrated that EMT may be involved in the promotion of the invasion and metastasis of human gastric cancer cells via 12-LOX; therefore, it may be a novel target for the treatment of gastric cancer.

\section{Acknowledgements}

Not applicable.

\section{Funding}

The present study was supported by the Key Clinical Specialty Discipline Construction Program of Fujian, China [grant no. (2012)149] and the Natural Science Foundation of Fujian Province, China (grant no. 2015J01476).

\section{Availability of data and materials}

The datasets used and/or analyzed during the current study are available from the corresponding author on reasonable request.

\section{Authors' contributions}

$\mathrm{CZ}$ performed the experiment, analyzed the experiment data and wrote the manuscript. MZ was responsible for the collection of the patient selection and tissue preparation. XW and JL were responsible for the design of experiment. ZC and $\mathrm{YH}$ were responsible for guiding the experimental technique, analysis of data and revising the manuscript. FC was accountable for designing the experiment, performing data interpretation and revising the manuscript.

\section{Ethics approval and consent to participate}

The present study was approved by the Ethics Committee of the Fujian Medical University Union Hospital (Fuzhou, China; reference no. 2014KY031).

\section{Consent for publication}

Written informed consent was obtained from each patient for the publication of their data.

\section{Competing interests}

The authors declare that they have no competing interests.

\section{References}

1. Chen W, Zheng R, Baade PD, Zhang S, Zeng H, Bray F, Jemal A, $\mathrm{Yu}$ XQ and He J: Cancer statistics in China, 2015. CA Cancer J Clin 66: 115-132, 2016.

2. Wadhwa R, Song S, Lee JS, Yao Y, Wei Q and Ajani JA: Gastric cancer-molecular and clinical dimensions. Nat Rev Clin Oncol 10: 643-655, 2013.

3. Pidgeon GP, Lysaght J, Krishnamoorthy S, Reynolds JV, O'Byrne K, Nie D and Honn KV: Lipoxygenase metabolism: Roles in tumor progression and survival. Cancer Metastasis Rev 26: 503-524, 2007.

4. Gondek T, Szajewski M, Szefel J, Aleksandrowicz-Wrona E, Skrzypczak-Jankun E, Jankun J and Lysiak-Szydlowska W: Evaluation of 12-lipoxygenase (12-LOX) and plasminogen activator inhibitor 1 (PAI-1) as prognostic markers in prostate cancer. Biomed Res Int 2014: 102478, 2014.

5. Singh AK, Kant S, Parshad R, Banerjee N and Dey S: Evaluation of human LOX-12 as a serum marker for breast cancer. Biochem Biophys Res Commun 414: 304-308, 2011.

6. Klampfl T, Bogner E, Bednar W, Mager L, Massudom D, Kalny I, Heinzle C, Berger W, Stättner S, Karner J, et al: Up-regulation of 12(S)-lipoxygenase induces a migratory phenotype in colorectal cancer cells. Exp Cell Res 318: 768-778, 2012.

7. Kang KH, Ling TY, Liou HH, Huang YK, Hour MJ, Liou $\mathrm{HC}$ and $\mathrm{Fu}$ WM: Enhancement role of host 12/15-lipoxygenase in melanoma progression. Eur J Cancer 49: 2747-2759, 2013. 
8. Hanahan D and Weinberg RA: Hallmarks of cancer: The next generation. Cell 144: 646-674, 2011.

9. Buehler D, Hardin H, Shan W, Montemayor-Garcia C, Rush PS, Asioli S, Chen H and Lloyd RV: Expression of epithelial-mesenchymal transition regulators SNAI2 and TWIST1 in thyroid carcinomas. Mod Pathol 26: 54-61, 2013.

10. Zhang H, Meng F, Liu G, Zhang B, Zhu J, Wu F, Ethier SP, Miller F and Wu G: Forkhead transcription factor foxq1 promotes epithelial-mesenchymal transition and breast cancer metastasis. Cancer Res 71: 1292-1301, 2011.

11. Hu X, Zhai Y, Kong P, Cui H, Yan T, Yang J, Qian Y, Ma Y, Wang F, Li H, et al: FAT1 prevents epithelial mesenchymal transition (EMT) via MAPK/ERK signaling pathway in esophageal squamous cell cancer. Cancer Lett 397: 83-93, 2017.

12. Kamikihara $\mathrm{T}$, Ishigami $\mathrm{S}$, Arigami $\mathrm{T}$, Matsumoto $\mathrm{M}$, Okumura H, Uchikado Y, Kita Y, Kurahara H, Kijima Y, Ueno S and Natsugoe $\mathrm{S}$ : Clinical implications of $\mathrm{N}$-cadherin expression in gastric cancer. Pathol Int 62: 161-166, 2012.

13. Natalwala A, Spychal R and Tselepis C: Epithelial-mesenchymal transition mediated tumourigenesis in the gastrointestinal tract. World J Gastroenterol 14: 3792-3797, 2008.

14. Kokkinos MI, Wafai R, Wong MK, Newgreen DF, Thompson EW and Waltham M: Vimentin and epithelial-mesenchymal transition in human breast cancer-observations in vitro and in vivo. Cells Tissues Organs 185: 191-203, 2007.

15. Tomita K, van Bokhoven A, van Leenders GJ, Ruijter ET, Jansen CF, Bussemakers MJ and Schalken JA: Cadherin switching in human prostate cancer progression. Cancer Res 60 3650-3654, 2000

16. Mahmood MQ, Ward C, Muller HK, Sohal SS and Walters EH Epithelial mesenchymal transition (EMT) and non-small cell lung cancer (NSCLC): A mutual association with airway disease. Med Oncol 34: 45, 2017.

17. Geng XL, Long WH, Hai J, Zhang Y, Zheng W, Zhang ZY and Du LX: The role of hexokinase 2 in the metastasis of hepatocellular carcinoma cells. Zhonghua Zhong Liu Za Zhi 38: 739-742, 2016 (In Chinese).

18. van Roy F and Berx G: The cell-cell adhesion molecule E-cadherin. Cell Mol Life Sci 65: 3756-3788, 2008.

19. Gao M, Li W, Wang $\mathrm{H}$ and Wang G: The distinct expression patterns of claudin-10, -14, -17 and E-cadherin between adjacent non-neoplastic tissues and gastric cancer tissues. Diagn Pathol 8 : 205, 2013.

20. Czyzewska J, Guzińska-Ustymowicz K, Ustymowicz M, Pryczynicz A and Kemona A: The expression of E-cadherin-catenin complex in patients with advanced gastric cancer: Role in formation of metastasis. Folia Histochem Cytobiol 48: 37-45, 2010

21. Yan HB, Wang XF, Zhang Q, Tang ZQ, Jiang YH, Fan HZ, Sun YH, Yang PY and Liu F: Reduced expression of the chromatin remodeling gene ARID1A enhances gastric cancer cell migration and invasion via downregulation of E-cadherin transcription. Carcinogenesis 35: 867-876, 2014.

22. Li Y, Chen CQ, He YL, Cai SR, Yang DJ, He WL, Xu JB and Zan WH: Abnormal expression of E-cadherin in tumor cells is associated with poor prognosis of gastric carcinoma. J Surg Oncol 106: 304-310, 2012.

23. Huang X, Qian Y, Wu H, Xie X, Zhou Q, Wang Y, Kuang W, Shen L, Li K, Su J, et al: Aberrant expression of osteopontin and E-cadherin indicates radiation resistance and poor prognosis for patients with cervical carcinoma. J Histochem Cytochem 63: 88-98, 2015.

24. Yun JA, Kim SH, Hong HK, Yun SH, Kim HC, Chun HK, Cho YB and Lee WY: Loss of E-Cadherin expression is associated with a poor prognosis in stage III colorectal cancer. Oncology 86: 318-328, 2014

25. Techasen A, Loilome W, Namwat N, Khuntikeo N, Puapairoj A, Jearanaikoon P, Saya $\mathrm{H}$ and Yongvanit P: Loss of E-cadherin promotes migration and invasion of cholangiocarcinoma cells and serves as a potential marker of metastasis. Tumour Biol 35: 8645-8652, 2014.

26. Washington $\mathrm{K}$ : 7th edition of the AJCC cancer staging manual: Stomach. Ann Surg Oncol 17: 3077-3079, 2010.

27. Chen F, Zhuang M, Zhong C, Peng J, Wang X, Li J, Chen Z and Huang Y: Baicalein reverses hypoxia-induced 5-FU resistance in gastric cancer AGS cells through suppression of glycolysis and the PTEN/Akt/HIF-1 $\alpha$ signaling patway. Oncol Rep 33: 457-463, 2015.
28. Rong S, Cao Q, Liu M, Seo J, Jia L, Boudyguina E, Gebre AK, Colvin PL, Smith TL, Murphy RC, et al: Macrophage 12/15 lipoxygenase expression increases plasma and hepatic lipid levels and exacerbates atherosclerosis. J Lipid Res 53: 686-695, 2012.

29. Nagasawa K, Kakuda T, Higashi $Y$ and Fujimoto S: Possible involvement of 12-lipoxygenase activation in glucose-deprivation/reload-treated neurons. Neurosci Lett 429: 120-125, 2007.

30. Dilly AK, Ekambaram P, Guo Y, Cai Y, Tucker SC, Fridman R, Kandouz $\mathrm{M}$ and Honn KV: Platelet-type 12-lipoxygenase induces MMP9 expression and cellular invasion via activation of PI3K/Akt/NF-кB. Int J Cancer 133: 1784-1791, 2013.

31. Yoshimura R, Inoue K, Kawahito Y, Mitsuhashi M, Tsuchida K, Matsuyama M, Sano $H$ and Nakatani T: Expression of 12-lipoxygenase in human renal cell carcinoma and growth prevention by its inhibitor. Int J Mol Med 13: 41-46, 2004.

32. Yoshimura R, Matsuyama M, Mitsuhashi M, Takemoto Y, Tsuchida K, Kawahito Y, Sano H and Nakatani T: Relationship between lipoxygenase and human testicular cancer. Int J Mol Med 13: 389-393, 2004.

33. Wong BC, Wang WP, Cho CH, Fan XM, Lin MC, Kung HF and Lam SK: 12-Lipoxygenase inhibition induced apoptosis in human gastric cancer cells. Carcinogenesis 22: 1349-1354, 2001.

34. Chen FL, Wang XZ, Li JY, Yu JP, Huang CY and Chen ZX: 12-lipoxygenase induces apoptosis of human gastric cancer AGS cells via the ERK1/2 signal pathway. Dig Dis Sci 53: 181-187, 2008.

35. Nie D, Nemeth J, Qiao Y, Zacharek A, Li L, Hanna K, Tang K, Hillman GG, Cher ML, Grignon DJ and Honn KV: Increased metastatic potential in human prostate carcinoma cells by overexpression of arachidonate 12-lipoxygenase. Clin Exp Metastasis 20: 657-663, 2003.

36. Gao X and Honn KV: Biological properties of 12(S)-HETE in cancer metastasis. Adv Prostaglandin Thromboxane Leukot Res 23: 439-444, 1995.

37. Honn KV, Tang DG, Gao X, Butovich IA, Liu B, Timar J and Hagmann W: 12-lipoxygenases and 12(S)-HETE: Role in cancer metastasis. Cancer Metastasis Rev 13: 365-396, 1994.

38. Torabizadeh Z, Nosrati A, Sajadi Saravi SN, Yazdani Charati J and Janbabai G: Evaluation of E-cadherin expression in gastric cancer and its correlation with clinicopathologic parameters. Int J Hematol Oncol Stem Cell Res 11: 158-164, 2017.

39. Anbiaee R, Mojir Sheibani K, Torbati P and Jaam H: Abnormal expression of e-cadherin in gastric adenocarcinoma, and its correlation with tumor histopathology and helicobacter pylori infection. Iran Red Crescent Med J 15: 218-222, 2013.

40. Lazăr D, Tăban S, Ardeleanu C, Dema A, Sporea I, Cornianu M, Lazăr E and Vernic C: The immunohistochemical expression of E-cadherin in gastric cancer; correlations with clinicopathological factors and patients' survival. Rom J Morphol Embryol 49: 459-467, 2008.

41. Stemmler MP: Cadherins in development and cancer. Mol Biosyst 4: 835-850, 2008.

42. Ma Y, Zheng X, Zhou J, Zhang Y and Chen K: ZEB1 promotes the progression and metastasis of cervical squamous cell carcinoma via the promotion of epithelial-mesenchymal transition. Int J Clin Exp Pathol 8: 11258-11267, 2015.

43. Zhao J, Yang C, Guo S and Wu Y: GM130 regulates epithelial-to-mesenchymal transition and invasion of gastric cancer cells via snail. Int J Clin Exp Pathol 8: 10784-10791, 2015.

44. Wang F, Li XK, Xu HY, Shan ZZ, Wang T, Yang ZC, He W, Wang LX and Fan QX: N-cadherin participated in invasion and metastasis of human esophageal squamous cell carcinoma via taking part in the formation of vasculogenic mimicry. Med Oncol 32: 480, 2015

45. Yi S, Yang ZL, Miao X, Zou Q, Li J, Liang L, Zeng G and Chen S: N-cadherin and P-cadherin are biomarkers for invasion, metastasis, and poor prognosis of gallbladder carcinomas. Pathol Res Pract 210: 363-368, 2014.

46. Ye J, Huang J, Xu J, Huang Q, Wang J, Zhong W, Lin X, Li Y and Lin X: ERp29 controls invasion and metastasis of gastric carcinoma by inhibition of epithelial-mesenchymal transition via PI3K/Aktsignaling pathway. BMC Cancer 17: 626, 2017.

47. Han M and Xu W: EMP3 is induced by TWIST1/2 and regulates epithelial-to-mesenchymal transition of gastric cancer cells. Tumour Biol 39: 1010428317718404, 2017. 
48. Song Y, Li ZX, Liu X, Wang R, Li LW and Zhang Q: The Wnt/ $\beta$-catenin and PI3K/Akt signaling pathways promote EMT in gastric cancer by epigenetic regulation via H3 lysine 27 acetylation. Tumour Biol 39: 1010428317712617, 2017.

49. Chen G, Tang N, Wang C, Xiao L, Yu M, Zhao L, Cai H, Han L, Xie $\mathrm{C}$ and Zhang Y: TNF- $\alpha$-inducing protein of Helicobacter pylori induces epithelial-mesenchymal transition (EMT) in gastric cancer cells through activation of IL-6/STAT3 signaling pathway. Biochem Biophys Res Commun 484: 311-317, 2017.

50. Zavadil J and Böttinger EP: TGF-beta and epithelial-to-mesenchymal transitions. Oncogene 24: 5764-5774, 2005.

51. Timmerman LA, Grego-Bessa J, Raya A, Bertrán E, Pérez-Pomares JM, Díez J, Aranda S, Palomo S, McCormick F, Izpisúa-Belmonte JC and de la Pompa JL: Notch promotes epithelial-mesenchymal transition during cardiac development and oncogenic transformation. Genes Dev 18: 99-115, 2004.
52. Huber MA, Azoitei N, Baumann B, Grünert S, Sommer A, Pehamberger H, Kraut N, Beug H and Wirth T: NF-kappaB is essential for epithelial-mesenchymal transition and metastasis in a model of breast cancer progression. J Clin Invest 114: 569-581, 2004.

53. Tashiro E, Henmi S, Odake H, Ino S and Imoto M: Involvement of the MEK/ERK pathway in EGF-induced E-cadherin down-regulation. Biochem Biophys Res Commun 477: 801-806, 2016.

This work is licensed under a Creative Commons Attribution-NonCommercial-NoDerivatives 4.0 International (CC BY-NC-ND 4.0) License. 